\title{
Uptake and long-distance transport of carbon in the marine phanerogam Posidonia oceanica
}

\author{
Maurice Libes ${ }^{1} \&$ Charles-François Boudouresque ${ }^{2}$ \\ ${ }^{1}$ Centre d'Océanologie de Marseille-Luminy, Station Marine d'Endoume, rue de la Batterie des Lions, F-13007 Marseille, \\ France \\ ${ }^{2}$ Laboratoire d'Ecologie du Benthos et de Biologie Végétale Marine, Faculté des Sciences de Luminy, F-13288 Marseille \\ Cedex 9, France
}

\begin{abstract}
Using the ${ }^{14} \mathrm{C}$ method in situ, we examined the transport of newly-formed photosynthates to different parts of Posidonia oceanica: leaves, rhizomes, roots, and epiphytes. After incubation with labelled carbon and post-incubation in situ for 6 to $24 \mathrm{~h}$, ca 2 to $30 \%$ of the fixed marker was found outside the incubated part. The results suggest a physiological relationship between the different leaf shoots of a given rhizome as well as between leaves and epiphytes. Rhizomes appear to serve as a storage and redistribution organ for photosynthesis products. Redistribution of such photosynthesis products is not haphazard but rather is directed to organs with high metabolic rates such as leaves in rapid growth phase or apical shoots undergoing division.
\end{abstract}

\section{INTRODUCTION}

Posidonia oceanica (Linnaeus) Delile is a marine phanerogam endemic to the Mediterranean Sea which grows as extended beds of long leaves grouped in clumps called 'shoots' (Fig. 1), from sea level down to 30 to $40 \mathrm{~m}$ depth. P. oceanica beds are at present the most crucial ecosystem to the life cycle of coastal Mediterranean benthos. Given its high primary production (Bay 1978, Ott 1980, Libes 1984a, Thelin \& Giorgi 1984) and the magnitude of the areas covered (Molinier \& Picard 1952), P. oceanica is a major source of oxygen in the water and a great bottom-stabilizing factor rendering the environment favourable for the development of a variety of plant and animal life (particularly fish).

As in most marine phanerogams, the leaves of Posidonia oceanica support a great many plant and animal epiphytes which can reach up to 20 to $30 \%$ of the biomass of the leaves (Jones 1968: Thalassia testudinum; Penhale 1977: T. testudinum and Zostera marina; Libes 1984a: P. oceanica). Apart from Diatomophyceae, the first algae which settle are multicellular Phaeophyta such as Myrionema orbiculare and Rhodophyta such as Dermatholiton littorale, FosLiella farinosa and Fosliella lejolisii, which constitute an encrusting stratum on the leaf surface. Then larger species, e.g. the Phaeophyta Giraudia sphacelarioides and Castagnea cylindrica (Ben 1971, Nowak 1984), overlie the crustaceous stratum. The epiphytic community probably plays an important role in the productivity and growth patterns of the host plant in terms of competition for available light energy and nutrients. For this reason research on epiphyte host plant relations in marine phanerogam communities now focuses on 3 aspects: (1) nutrient uptake by marine phanerogams, (2) transport of newly-formed photosynthesis products from one part of the plant to another, and (3) transfer of organic and mineral material between leaves and epiphytes. Investigations carried out mainly on Zostera marina and Thalassia testudinum demonstrated the existence of complex interrelations in the different compartments of the system (sediment, leaves, epiphytes, water), insofar as the principal elements (carbon, nitrogen, phosphorus) are concerned (McRoy \& Barsdate 1970, Harlin 1973, 1975, McRoy \& Goering 1974, Penhale 1977). Depending on environmental conditions, marine phanerogams can obtain the nutrients necessary for growth from the sediment, as well as from the surrounding water through the leaves (Thursby \& Harlin 1982). But regardless of how they are absorbed (by roots or by leaves), these nutrients are distributed throughout the plant (McRoy \& Barsdate 1970, Fresi \& Saggiomo 1981) 


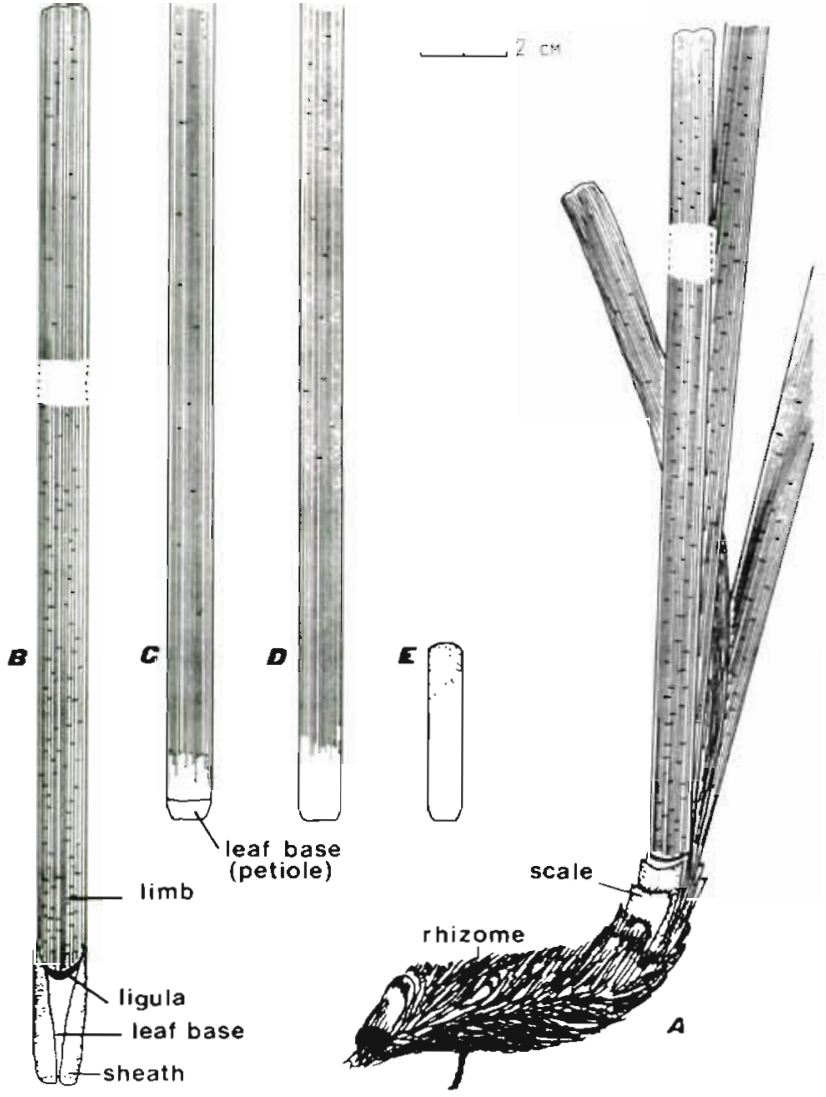

Fig. 1. Posidonia oceanica (A). Shoot of leaves on a plagiotropic rhizome. The remaining petioles (scales) of dead leaves give the rhizome its 'fuzzy' appearance. (B) Adult leaf with a wrapping petiole. (C, D) Intermediate leaves. (E) Juvenile leaf

and can reach epiphytes (Harlin 1973, 1975, McRoy \& Goering 1974, Wetzel \& Penhale 1979, Penhale \& Thayer 1980).

The transport of photosynthesis products and minerals within marine plants has been documented particularly in Phaeophyceae (Laminariales, Fucales) (Floc'h \& Penot 1972, Lüning et al. 1972, Buggeln 1976, 1977 , 1978, Emerson et al. 1982, Schmitz 1982, Diouris \& Floc'h 1984, Manley 1984, Penot et al. 1985), and in some marine phanerogams (Zostera marina: Harlin 1973, 1975, Penhale \& Thayer 1980, Brix \& Lyngby 1985; Zostera americana, Thalassia testudinum and Halodule wrightii: Wetzel \& Penhale 1979; Phyllospadix scoulerii: Harlin 1973). In Posidonia oceanica, only phosphorus transport from the roots to the leaves has been confirmed so far (Fresi \& Saggiomo 1981).

Although a number of studies have been devoted to the bionomics and dynamics of Posidonia oceanica beds (Boudouresque et al. 1980), information about the basic physiology of this plant is scarce and incomplete. We have attempted to identify some of the compart- ments in the $P$, oceanica ecosystem and to study direction and magnitude of transport of organic material within and between these compartments. Using the ${ }^{14} \mathrm{C}$ method in situ, we studied variations in the photosynthetic uptake of carbon i.e. between leaves of a given shoot and between the different parts of a given leaf. We also tried to determine if newly-formed photosynthetic products were translocated from a shoot to adjacent shoots, and if a transfer of organic compounds could occur between the plant and its epiphytes.

\section{MATERIAL AND METHODS}

Study area. All experiments were carried out in a bed of Posidonia oceanica ( 400 to 600 shoots $\mathrm{m}^{-2}$ ) in the Bay of Port-Cros (French Mediterranean coast) at a depth of $2.5 \mathrm{~m}$.

In situ experiments. All experiments were performed in situ using SCUBA diving equipment. For each experiment, one shoot of Posidonia oceanica with its epiphytes, the rhizome of which is orthotropic (vertical growth), was isolated in a watertight, transparent plexiglas incubation chamber (Fig. 2). This incubator had a volume of 4.11 and was equipped with a stirring device (Bay 1978). A rubber seal wrapped tightly around the orthotropic rhizome of the shoot as well as around the bottom of the incubator isolated the system from the surrounding waters and the sediment without cutting the enclosed leaves off from the rest of the plant (Fig. 2). The water seal was checked several times using dyes (India ink, methylene blue).

At the beginning of the experiment, $40 \mu \mathrm{Ci}(88.8 \times$ $10^{6} \mathrm{dpm}$ ) of ${ }^{14} \mathrm{C}$ as $\mathrm{NaHCO}_{3}$ (specific activity $55 \mu \mathrm{Ci}$ $\mu \mathrm{mol}^{-1}$ ) were injected into the chambers. Thus 0.72 umol of $\mathrm{NaHCO}_{3}$ was added to the 4.1 of seawater contained in the incubator. The quantity of carbon added, $2.1 \mu g \mathrm{C}^{-1}$, was very small compared to the initial carbon concentration in the surrounding water which averaged $26.5 \mathrm{mgC}^{-1}$ at the experimental site (Table 1). Thus the steady state of the system was not perturbated by this addition.

Two types of experiments were devised to study transport of photosynthesis products: short incubations (about $2 \mathrm{~h}$ ) to serve as a reference and long incubations (about 6h) to allow synthesis of greater amounts of photosynthesis products. After incubation in the labelled medium, the incubation chamber was carefully removed along with the labelled water in it but the labelled shoot was left in situ for 6 to $24 \mathrm{~h}$ for transport of photosynthetic products. This phase of the experiment was referred to as 'postincubation'

The washing off of leaf-adsorbed labelled water following removal of the experimental chamber (less 


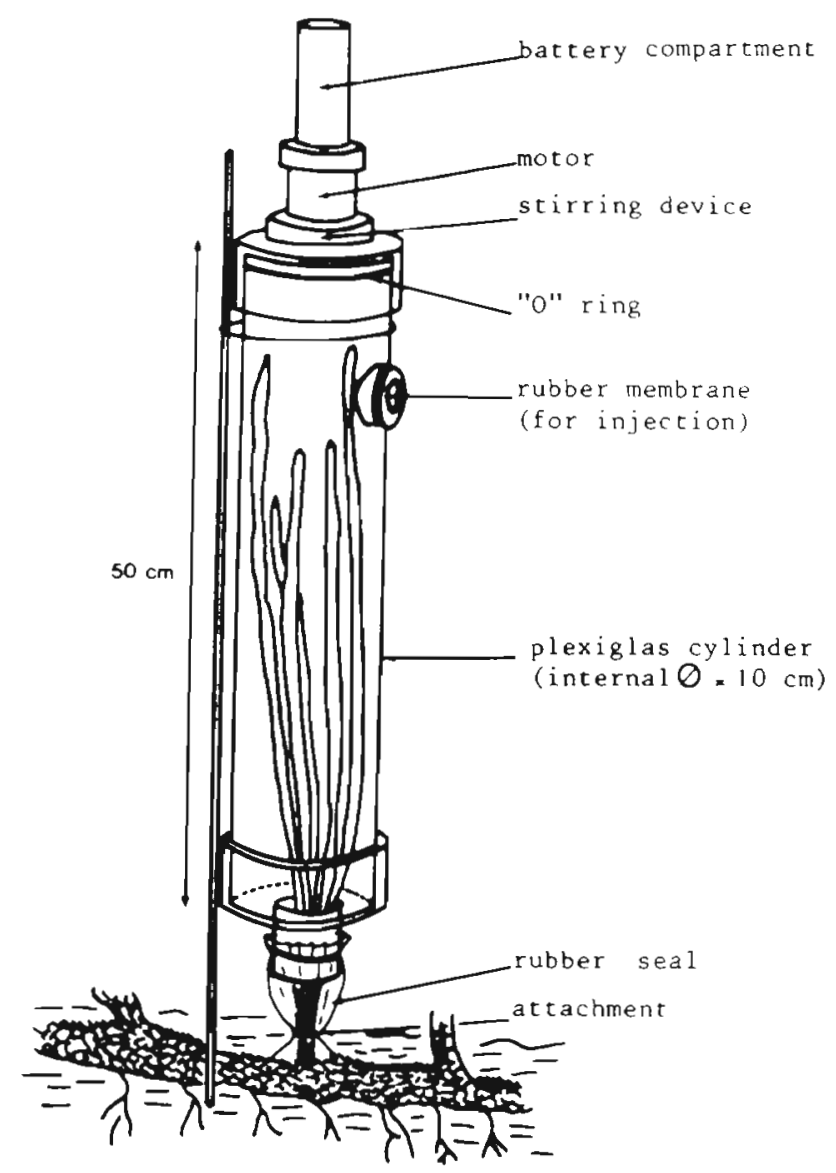

Fig. 2. An incubation chamber enclosing a shoot of Posidonia oceanica leaves in situ

than $0.5 \%$ of the chamber water) had no particular influence on the reliability of the experiment, given the extremely high dilution rate occurring in seawater.

The postincubations were carried out for various durations, from 5 to $24 \mathrm{~h}$ (Table 2). Two of them (Expt 5: 28 May 1981 and Expt 9: 18 May 1982), were performed in darkness over one night. After postincubation, the incubated shoot along with the whole rhizome system (roots and adjacent shoots belonging to the same rhizome) were removed from the sediment. Each individual shoot was carefully rinsed in seawater, quickly dried on adsorbent paper, isolated in a plastic bag in order to avoid cross-contamination, then quickly frozen in dry ice pending laboratory treatment. We also collected some shoots located $1 \mathrm{~m}$ from the experimental site to analyse the radioactivity background level in the leaves. Finally, dark fixation experiments were carried out (Libes 1984a) in order to evaluate the amount of ${ }^{14} \mathrm{C}$ fixed via dark carboxylation reactions, and to compare it with our results of transfer experiments.

We performed 9 experiments to assess transport of photosynthetic products: 2 short incubation experiments (Expts 1 and 2: 5 and 25 Mar 1981) and 7 long incubation experiments with postincubation phase (Expts 3 to 9: 23 and $24 \mathrm{Apr}, 28 \mathrm{May}, 26$ Jun, $30 \mathrm{Sep}$ 1981; 11 Jan, 18 May 1982). In 3 experiments (Expts 6, 7 and 9) a shoot adjacent to the incubated shoot (belonging to the same rhizome system) was placed in a dark chamber for the total duration of the experiment (incubation + postincubation).

In the course of incubation, several physical and chemical measurements were made in the surrounding waters. These selective measurements are presented in Table 1, and included: $\mathrm{pH}$ and alkalinity (according to the method of Strickland \& Parsons 1972); water temperature and salinity (the latter always around 37 to $38 \%$ ); photon irradiance (in $\mathrm{E} \mathrm{m}^{-2} \mathrm{~h}^{-1}$ ) reaching the leaves (quantameter from Lambda Instruments LI550 connected to an underwater photocell LI 192 SB).

Laboratory. Sorting the shoots and collection of epiphytes. Each frozen shoot was placed on a working table covered with aluminium foil (which was changed after each shoot treatment). In order to avoid possible contamination by ${ }^{14} \mathrm{C}$ from one part to another part of the shoot, or from leaves to epiphytes, each shoot was divided into its different parts, and epiphytes were removed before complete thawing.

Following Giraud (1979), we distinguished adult,

Table 1. Measurements of $\mathrm{pH}$, total dissolved inorganic carbon, temperature, and salinity of the surrounding water at the beginning of each experiment. Expts 1 \& 2 had 2 replicates. Bay of Port-Cros, $2.5 \mathrm{~m}$ depth, except Expt 8: $25 \mathrm{~m}$ depth

\begin{tabular}{|c|c|c|c|c|c|c|c|c|c|c|c|}
\hline \multirow[t]{2}{*}{ Parameter } & \multicolumn{11}{|c|}{ Experiment no. } \\
\hline & \multicolumn{2}{|c|}{1} & \multicolumn{2}{|c|}{2} & \multirow{2}{*}{$\frac{3}{8.25}$} & \multirow{2}{*}{$\frac{4}{8.45}$} & \multirow{2}{*}{$\frac{5}{8.45}$} & \multirow{2}{*}{$\frac{6}{8.10}$} & \multirow{2}{*}{$\frac{7}{7.90}$} & \multirow{2}{*}{$\begin{array}{c}8 \\
7.80\end{array}$} & \multirow{2}{*}{$\begin{array}{c}9 \\
8.20\end{array}$} \\
\hline $\mathrm{pH}$ & 8.35 & 8.40 & 8.40 & 8.10 & & & & & & & \\
\hline $\mathrm{mg} \mathrm{Cl} \mathrm{I}^{-1}$ & 26.35 & 25.90 & 24.71 & 26.82 & 26.03 & 26.39 & 25.06 & 29.05 & 27.00 & 26.80 & 27.51 \\
\hline${ }^{\circ} \mathrm{C}$ & 13 & 13 & 13 & 13 & 15 & 14 & 16 & 21 & 21 & 12 & 18 \\
\hline $\mathrm{S} \%$ & & -38 & & 38 & $37-38$ & $37-38$ & $37-38$ & $37-38$ & $37-38$ & $37-38$ & $37-38$ \\
\hline $\begin{array}{l}\text { Irradiance } \\
\left(\mathrm{E} \mathrm{m}^{-2} \mathrm{~h}^{-1}\right)\end{array}$ & 2.34 & 3.38 & 2.25 & 2.50 & 0.5 & 0.8 & 0.6 & 1.15 & 2.15 & 0.15 & 0.28 \\
\hline
\end{tabular}




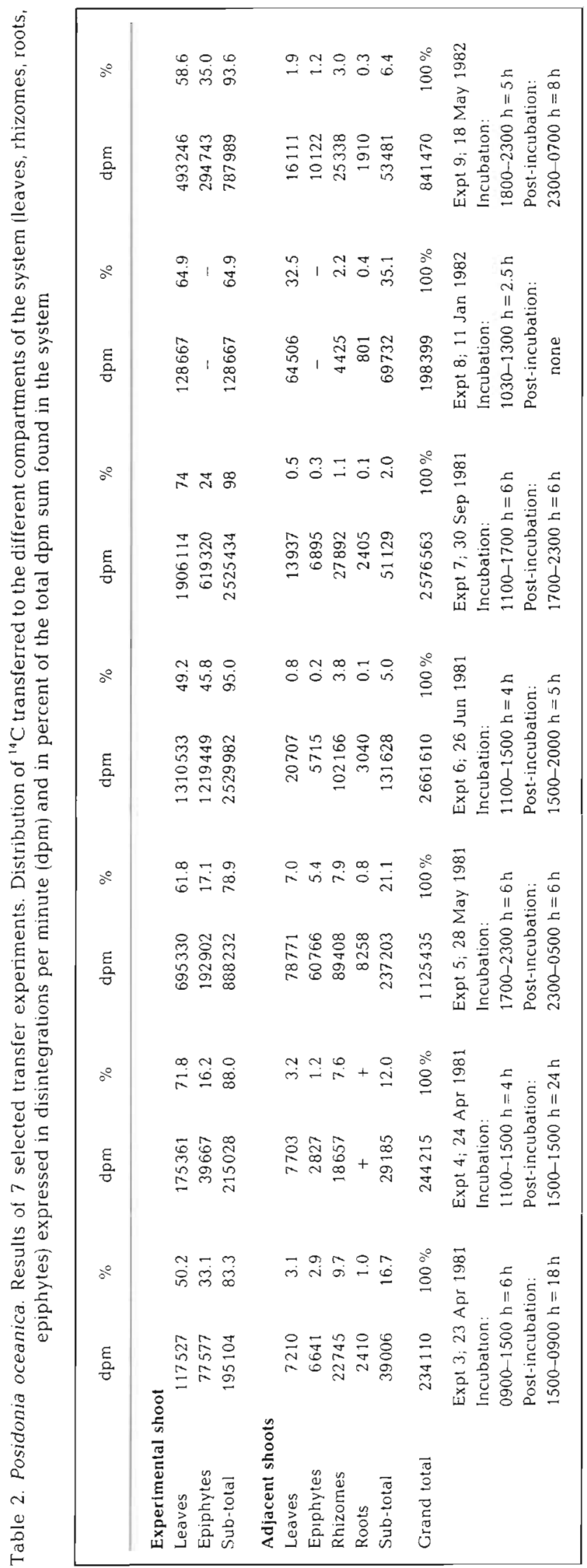

intermediate and juvenile leaves (Fig. 1). Adult leaves which had practically stopped growing had a distinct base (sheath) wrapped around the other leaves. Intermediate leaves were those over $5 \mathrm{~cm}$ long without a distinct base; they were in the rapid growth phase. Finally, juvenile leaves (shorter than $5 \mathrm{~cm}$ and without a distinct base) appeared in the center of the shoot (Caye \& Rossignol 1983); they were limp and almost totally devoid of chlorophyl. All these leaves were separated, measured (from end to end) and numbered according to their rank in the shoot from the youngest (in the center of the shoot marked $\mathrm{L}_{1}$ ) to the oldest (outermost on the shoot marked $\mathrm{L}_{n}$ ) except for juvenile leaves. In some cases, to assess longitudinal transport, the leaves were cut into segments of $10 \mathrm{~cm}$.

Epiphytes were removed on still-frozen leaves by thoroughly scraping both sides of the leaf with a razor blade and all epiphytes from the same shoot were combined. The thick cuticle on the leaf surface makes it possible to remove almost all epiphytes without damaging the leaf. A new razor blade was used after each treated shoot. Obviously - as also discussed by Penhale (1977) - this method was not selective for photosynthetic organisms; the material collected includes a range of organic (bacteria, fungi, bryozoans, foraminifers, hydroids) as well as inorganic material (silt). We found that the ash content in the epiphyte compartment can reach 40 to $50 \%$ of the total dry matter weight of the collected material (Libes 1984a, b). Rhizomes were 'scaled' (removal of the bases of dead leaves), measured from end to end, and cut into pieces $2 \mathrm{~cm}$ long. Roots were cut into pieces $10 \mathrm{~cm}$ long.

During the thawing process, small amounts of liquid, (probably made of cell sap, remaining seawater on the leaves, and condensation) appeared, especially from leaves densely covered with epiphytes. In order to avoid contamination from part to part of the shoot, and to control a possible underestimation of the ${ }^{14} \mathrm{C}$ fixed, the shoots were sorted before complete thawing, and the leaking liquid was wiped with a GF/C filter, the radioactivity of which was then analysed in the same manner as all other samples (see below). Although the filter radioactivity was very small (less than $1 \%$ of total shoot radioactivity), it was taken into account and added to the total radioactivity.

Combusting the samples. After lyophilization, each sample was weighed, then combusted separately in a Packard Tri-Carb B306 oxidizer prior to counting the assimilated ${ }^{14} \mathrm{C}$ in a liquid scintillation spectrometer. All counts were corrected for background, recovery efficiency after combustion, and counting efficiency. Disintegrations per minute were converted to milligrams of carbon ( $\mathrm{mg} \mathrm{C}$ ) in accordance with the isotopic dilution ratio at the start of the experiment i.e. $88.8 \times$ $10^{6} \mathrm{dpm}$ for $106 \mathrm{mg} \mathrm{Cl}^{-1}$ (Vollenweider 1974). 


\section{RESULTS}

\section{Zones of carbon uptake}

Leaf rank

In a given shoot, the amount of carbon fixed by a leaf (per unit dry matter weight and time expressed as $\mu \mathrm{g} \mathrm{C}$ $[\mathrm{g} \mathrm{DMW}]^{-1} \mathrm{~h}^{-1}$ ) varied according to its insertion rank in the shoot (Fig. 3). Regardless of the season, greatest carbon uptake was regularly observed in intermediate leaves. In Expt 1 (5 Mar), involving a shoot with 6 leaves, about $70 \%$ of the total carbon fixed after $2 \mathrm{~h}$ of incubation was found in intermediate leaves 2, 3 and 4 (Fig. 3A). Adult leaves always had a lower productivity than intermediate leaves. Finally, the uptake of carbon by juvenile leaves which were almost totally devoid of chlorophyll (Libes 1984b) and received very little light, because of their location in the center of the shoot, was very low but nevertheless clearly detectable.

\section{Location along leaf}

After short incubation times (about 2 h, without postincubation), the highest amounts of ${ }^{14} \mathrm{C}$ were measured in the middle part of intermediate leaves (Fig. 3). In Expts 1 and 2, 50 to $60 \%$ of the total carbon fixed by the shoot was found in the middle part of the leaves (as compared to 20 to $30 \%$ at the apical part and 10 to $20 \%$ at the base).

\section{Photosynthate transfer}

Direction and localization of transfer

In experimental shoots after a short incubation (2h) without postincubation, most of the labelled products were found in the middle part of intermediate leaves (Fig. 3). After longer incubation (4h) followed by a $24 \mathrm{~h}$ postincubation phase (Expt 4; Fig. 4A), the highest quantities of ${ }^{14} \mathrm{C}$ were measured in the basal part of intermediate leaves which includes the meristem (zone of cell division) and in the chlorophyll-free sheath of adult leaves. In the rhizomes, the greatest amount of radioactivity was located under the incubated shoot (Fig. 5). From this location, radioactivity showed a pattern of decreasing concentration indicative of the migration of photosynthesis products (Fig. $5 \mathrm{a}$ to d). In Expt 6 (Fig. 5c) almost all the radioactivity was found in the apical part of the rhizome. The amount of photosynthesis product transferred to the roots was less than to the other parts of the plant (Fig. 5a, bi Table 2). As was the case in the rhizome, the roots located directly under the experimental shoot displayed the highest concentrations of radioactivity.

Labelled products were also detected in significant quantities in the leaves of adjacent unincubated shoots,
Fig. 3. Posidonia oceanica. Distribution of newly-formed photosynthesis products fexpressed as $\mu \mathrm{g} \mathrm{C} \mathrm{g} \mathrm{DMW}^{-1}$ ) in the different leaves of shoots and as a function of distance from the leaf base after a $2 \mathrm{~h}$ incubation with labelled solution. Shaded areas correspond to the highest value recorded in a given leaf. (A, B) Expt 1 (5 Mar 1981); (C, D) Expt 2 (25 Mar 1981); depth $2.5 \mathrm{~m}$
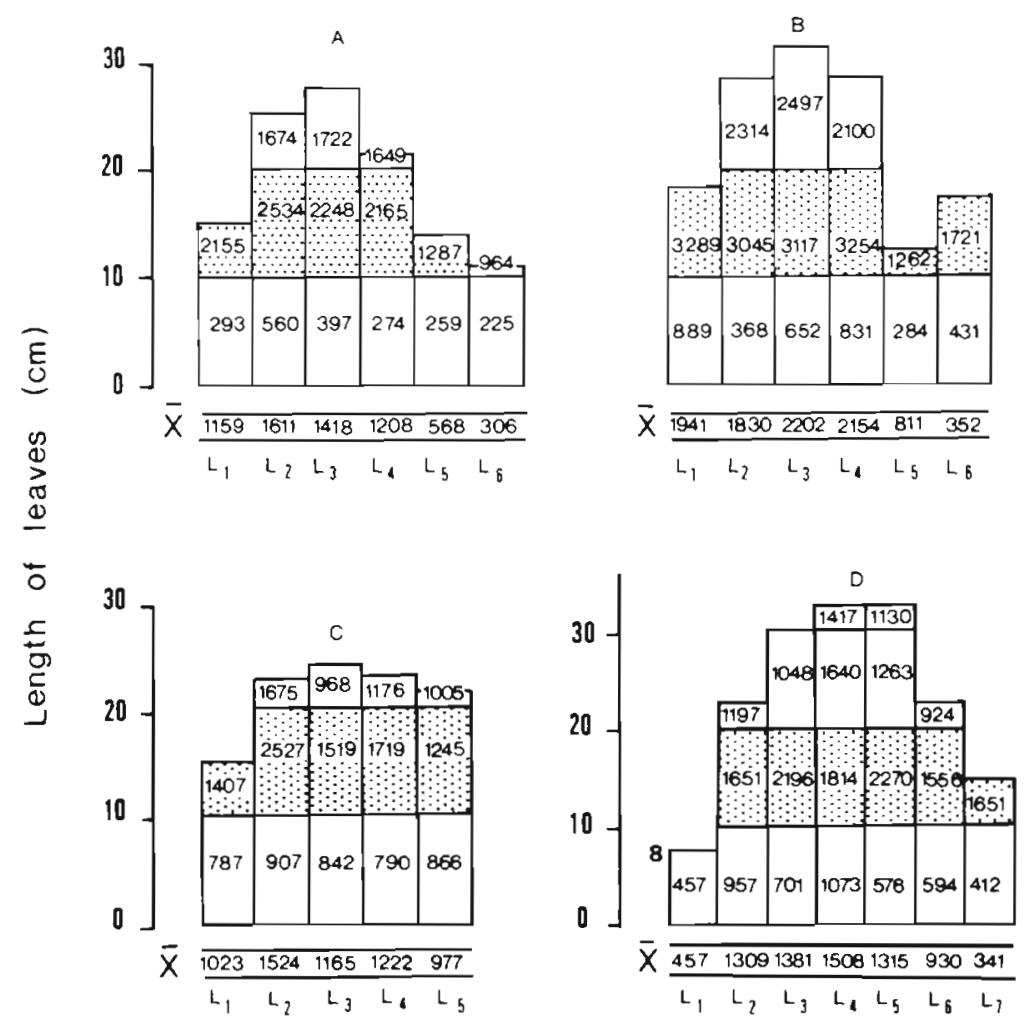

Leaf rank 

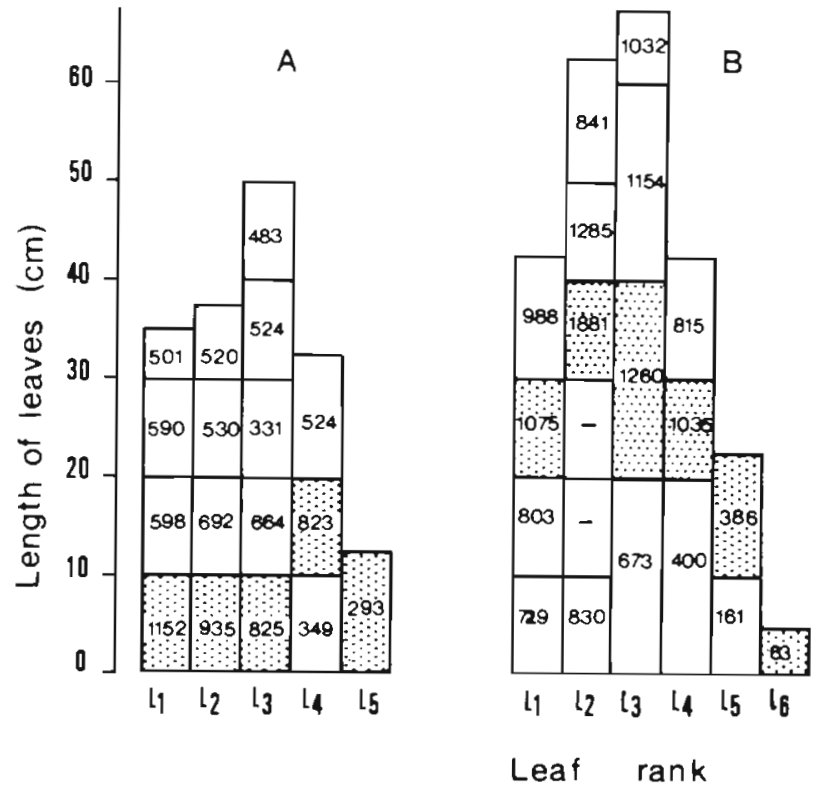

Fig. 4. Posidonia oceanica. Productivity of leaves (in $\mu \mathrm{g} \mathrm{C}$ [g DMW $]^{-1}$ ) as a function of distance from leaf base. Shaded areas correspond to the highest value recorded in a given leaf. (A) 4 h incubation +24 h postincubation (24 Apr 1981; Expt 4).

(B) Shoot $V$ used for a transfer experiment performed on 28 May 1981 (Expt 5); $6 \mathrm{~h}$ incubation $+6 \mathrm{~h}$ postincubation but growing on the same rhizome as the experimental shoot, as well as in their epiphytes (Fig. 5a to $\mathrm{c}_{\text {; }}$ Table 2). ${ }^{14} \mathrm{C}$ repartition in these shoots did not occur haphazardly. Intermediate leaves in Rank 2 and 3 were the main recipients of transferred ${ }^{14} \mathrm{C}$ (Friedmann rank test, in Siegel 1956): $\chi_{\text {obs }}^{2}=10.11>\chi_{0.05}^{2}=9.49$ with 4 df; Table 3). Transferred labelled products appeared to accumulate in the apical parts of the leaves. For instance in Shoot XVIII (Expt 5; Fig. 5) the distribution was as follows: (1) base: $2.9 \mu \mathrm{g} \mathrm{C}(\mathrm{g} \mathrm{DMW})^{-1}$ i (2) middle: $12.7 \mu \mathrm{g} \mathrm{C}(\mathrm{g} D M W)^{-1}$; (3) tip: $19.8 \mu \mathrm{g} \mathrm{C}(\mathrm{g}$ DMW) ${ }^{-1}$. Finally, shoots left in a dark chamber for the total duration of Expts 6,7 and 9 appeared to be labelled equally to other adjacent shoots (Table 4).

\section{Magnitude and speed of transfer}

It was assumed that all the ${ }^{14} \mathrm{C}$ measured in the various compartments of the system studied here (leaves, epiphytes, rhizomes, roots) came from photosynthetic assimilation by the incubated shoot. Accordingly, the amount of radioactivity measured in each of the other compartments was calculated as a percent of total uptake (Table 2). In our system, the total amount

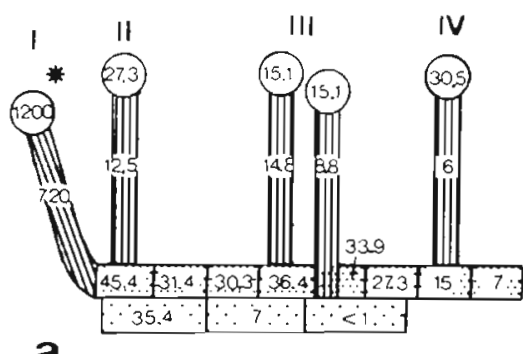

a

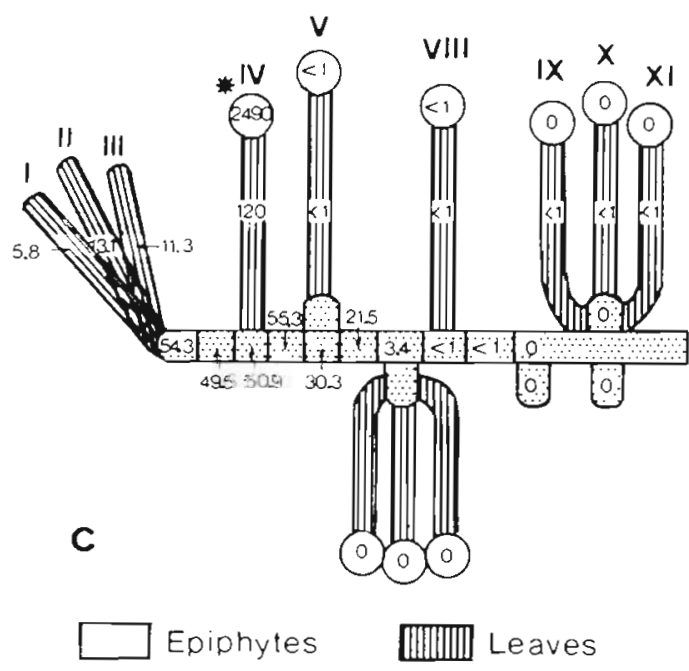

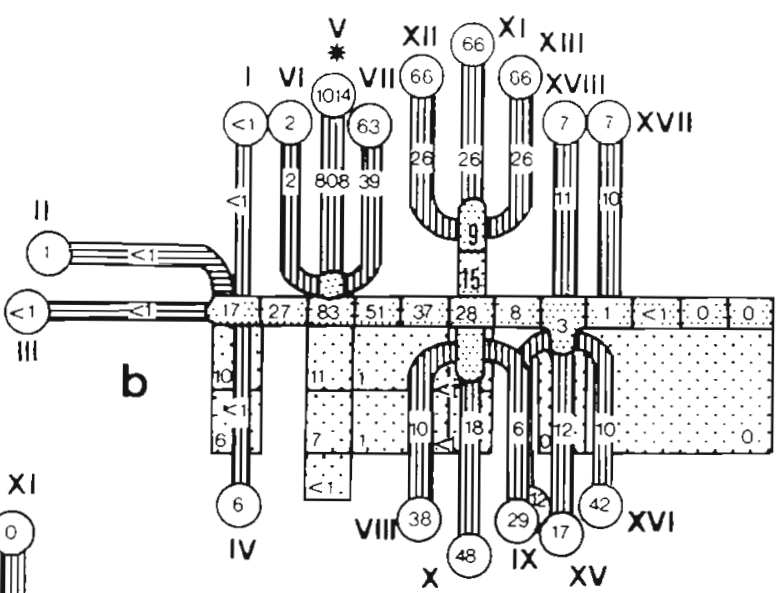

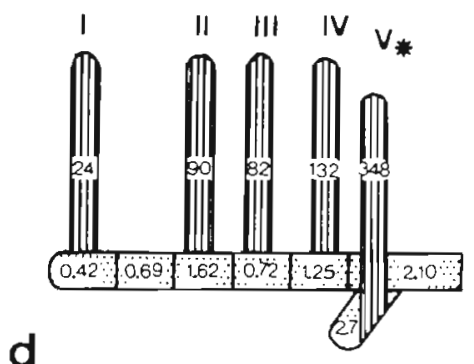

d

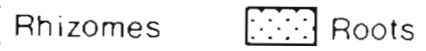

Fig. 5. Posidonia oceanica. Distribution of newly-formed photosynthesis products (in $\mu \mathrm{g} C$ [g DMW] ${ }^{-1}$ ), transferred to the different compartments of a $P$. oceanica system after an incubation in ${ }^{14} \mathrm{C}$ solution and in situ postincubation. Asterisk indicates the incubated shoot. Expts 4 (a), 5 (b) and 6 (c): depth $2.5 \mathrm{~m}$. Expt 8 (d) at depth $25 \mathrm{~m}$, performed on shoots with epiphyte-free leaves 
Table 3. Posidonica oceanica. Amounts of translocated radioactivity (expressed in dpm $[\mathrm{g} \mathrm{DMW}]^{-1}$ ) in the different leaves of some shoots (Expt 5). In each shoot, the leaf displaying the lowest amount of transferred carbon (in parentheses) was designated as Rank 1 for the Friedmann test. (Since adult leaves in Rank 6 were often missing, this rank was deleted from the Friedmann test)

\begin{tabular}{|c|c|c|c|c|c|}
\hline \multirow{2}{*}{ Shoot } & \multicolumn{5}{|c|}{ Leaf Rank } \\
\hline & $\mathrm{L}_{1}$ & $L_{2}$ & $L_{3}$ & $L_{4}$ & $L_{5}$ \\
\hline I & $440 \quad(5)$ & 335 (3) & 307 (2) & 337 (4) & 110 (1) \\
\hline II & 625 (4) & 244 (1) & 391 (3) & 271 (2) & 2186 \\
\hline III & $636 \quad(3)$ & $716 \quad(5)$ & $573(1)$ & $606 \quad(2)$ & $664 \quad(4)$ \\
\hline IV & 566 (3) & $673(4)$ & $550 \quad(2)$ & 435 (1) & $898 \quad(5)$ \\
\hline V & 649518 (3) & 858627 (5) & $734924 \quad(4)$ & $445002 \quad(2)$ & 170696 (1) \\
\hline VI & 4162 & 22147 (4) & 60872 & 3425 & 1284 \\
\hline VII & 1465 & 2030 & $793(2)$ & 4180 & 763 (1) \\
\hline VIII & 6592 (3) & 9139 (5) & 7020 & 3088 (2) & 2142 (1) \\
\hline$I X$ & 7258 & $6177(4)$ & $2302(2)$ & 5400 & 1691 (1) \\
\hline $\mathrm{X}$ & 2999 (1) & 38447 (5) & 10100 & 5355 & $3823(2)$ \\
\hline XIV & 11193 & 3991 (1) & 12840 & 4535 (2) & 5895 (3) \\
\hline$X V$ & 9327 (3) & 10700 & $12004 \quad(5)$ & $714(2)$ & 215 (1) \\
\hline XVI & 4562 & 3364 & $20808 \quad(5)$ & $928(2)$ & 450 \\
\hline XVII & 2610 & 4384 & $7076(4)$ & 16000 & 1953 \\
\hline Rank sum $=$ & 46 & 51 & 48 & 37 & 28 \\
\hline & & & $\chi_{0.05}^{2}=9.49$ & & \\
\hline
\end{tabular}

Table 4. Posidonia oceanica. Amount of radioactivity, expressed as dpm (g DMW $)^{-1}$, found in shoots left in a dark chamber during incubation and postincubation phases of Expts 6,7 \& 9

\begin{tabular}{|lccc|}
\hline & Expt 6 & Expt 7 & \multicolumn{1}{c|}{ Expt 9 } \\
\hline $\begin{array}{l}\text { P. oceanica } \\
\text { Epiphytes }\end{array}$ & 730 & 310 & 544 and 398 \\
\hline
\end{tabular}

of radioactivity measured outside the experimental shoot ranged from 2 to $35 \%$ (Table 2). Discounting radioactivity in the epiphytes of the experimental shoot (since nothing is known about the extent of exchanges of organic compounds between leaves and epiphytes), the percentages of transferred ${ }^{4} \mathrm{C}$ were $24.9,14.3,25.5$, $9.1,2.6$, and $9.8 \%$ for experiments lasting (incubation + postincubation) 24, 28,12, 9,12, and $13 \mathrm{~h}$ (Expts 3 to 9. respectively, except Expt 8 in which shoots were epiphyte-free). Under our experimental conditions, transfer was generally no longer detectable at distances greater than $15 \mathrm{~cm}$ from the experimental shoot. Transfer can thus be calculated to occur at a maximal rate of about 2 to $5 \mathrm{~cm} \mathrm{~h}^{-1}$ i.e. $15 \mathrm{~cm}$ (rhizomes) $+40 \mathrm{~cm}$ (leaves) in 12 to $24 \mathrm{~h}$.

\section{DISCUSSION AND CONCLUSIONS}

\section{Zones of carbon uptake in leaves}

The photosynthetic uptake of carbon in Posidonia oceanica depends largely on leaf age (i.e. rank of the leaf in the shoot). Productivity is at its highest in intermediate leaves (Fig. 3), which are the richest in chlorophyl (Libes 1984b) and the fastest-growing (Ott 1980, Caye \& Rossignol 1983, Thelin \& Giorgi 1984). Uptake is regularly much lower in adult leaves which have finished their growth cycle (Ott 1980), are poorer in chlorophyll pigments, and are often totally covered with epiphytes. Thus productivity, as chlorophyl synthesis, peaks during the rapid growth phase and then, the leaf having reached maturity, decreases.

Along a given leaf, productivity is always higher in the middle part than in the basal and apical parts (Fig. 3). This result is consistent with the facts that basal parts of the leaves are poor in chlorophyll (Drew 1978, Libes 1984b) and less accessible to light (in summer, for example, when foliage is fullest, only $5 \%$ of the incoming light reaches the base of the shoot), and that the apical parts are always thickly covered with epiphytes, making the leaf less accessible to light.

Finally, for a given irradiance, 2 factors appear to strongly influence productivity in Posidonia oceanica, namely, the chlorophyll content in the leaf (and in different parts of leaf), and the quantity of epiphytes on the surface of the leaf. Such age-dependent variations in leaf metabolism have been also reported in $P$. oceanica by Drew (1978) and Pirc (1985) and in Zostera americana by Harrison (1978).

The uneven distribution of chlorophyll and local productivity differences from leaf to leaf, and on a given leaf, in Posidonia oceanica can have great repercussions on methodology. Measurements performed without regard to the location of the leaf in the shoot (Drew 
\& Jupp 1976) can give misleading results. As was shown by Hatcher (1977) in Laminaria longicruris, not only is it difficult to delineate a segment representative of the plant overall production, but also cutting that segment off from the rest of the plant is highly detrimental to plant metabolism. It is thus essential, as suggested by Wetzel (1974), to assess the productivity of the plant as a whole. In P. oceanica beds, given the complex interrelationships between the shoots, it is difficult to delineate a functional unity. But, for practical reasons, it is necessary to use the individual shoot as the experimental unit.

Our finding concerning the location of the most active zones of photosynthesis in Posidonia oceanica leaves raises an important point about physiology. After short incubation, the amount of ${ }^{14} \mathrm{C}$ in young leaves and in the sheath of adult leaves, both of which are almost completely devoid of chlorophyll and inaccessible to light, cannot be explained on the basis of photosynthesis alone and argues for the occurrence of an early transfer of photosynthesis products towards the meristematic basal zones.

\section{Long-distance transport of photosynthesis products}

When a shoot of Posidonia oceanica was labelled with ${ }^{14} \mathrm{C}$ for about $6 \mathrm{~h}$, and left in situ for 4 to $24 \mathrm{~h}$ thereafter (postincubation), ${ }^{14} \mathrm{C}$ was found in different morphological compartments of the system: rhizomes, roots, adjacent shoots and their epiphytes (Fig. 5). The highest levels of radioactivity were measured in the rhizome. The roots appeared to be much less supplied with carbon. Transfer of organic compounds from leaves to roots is the simplest explanation for the presence of ${ }^{14} \mathrm{C}$ in roots and rhizomes since these organs are not capable of photosynthesis. Conversely, one could hypothesize that the ${ }^{14} \mathrm{C}$ found in adjacent shoots and their epiphytes may be assimilated (via photosynthetic or non-photosynthetic reactions) from the $\mathrm{CO}_{2}$ and/or from the excreted organic carbon released by the experimental shoot during the postincubation phase (during this phase the labelled shoot is no longer inside the incubation chamber). Moreover it is also possible, due to the fact that $P$. oceanica is crisscrossed (leaves, rhizomes and roots) by a network of air ducts (Pottier 1934), that $\mathrm{CO}_{2}$ transits via the lacunar system (aerarium) from the experimental shoot to adjacent shoots where it may then be metabolized.

In order to determine such possible contamination (by photosynthetic reactions), the postincubations of Expts 5 and 9 were carried out at night (from 2300 to 0500 h) in total darkness. Furthermore, Expts 6, 7 and 9 were carried out in which one shoot adjacent to the incubated shoot was isolated in a dark incubator for the duration of the experiment (incubation + postincubation).

Despite these dark experimental conditions which precluded photosynthetic reassimilation of both respiratory ${ }^{14} \mathrm{CO}_{2}$ losses and ${ }^{14} \mathrm{CO}_{2}$ circulating in air ducts, ${ }^{14} \mathrm{C}$ was found in significant quantities in all adjacent shoots including those isolated in the dark chamber (Table 4). The amount of ${ }^{14} \mathrm{C}$ fixed in the dark via dark carboxylation reactions (Libes 1984a) by shoots incubated in a highly labelled medium was often of the same order of magnitude as that measured in some adjacent shoots left in open waters for the postincubation phase. A large part of the radioactivity found in adjacent shoots could not be explained solely on the base of dark carboxylation reactions.

It can thus be concluded that 'long-distance' transport of photosynthesis products occurred through the rhizomes towards roots and other shoots. Rhizomes connect the different shoots of leaves which do not function independently but rather as a unit. A substantial fraction of the photosynthesis products is exported to the rhizome, and then redistributed mainly to organs with high metabolic activity such as intermediate leaves in rapid growth phase (Table 3). Depending on the position of the incubated shoot on the rhizome, tranfer was acropetal (toward the plagiotropic apex) or counter-acropetal. In Expt 6 (Fig. 5c) transfer was certainly influenced by the presence of an apical plagiotropic shoot undergoing division. Our results (Expts 5 and 9; Fig. 5 \& Table 2) also indicate that translocation occurs even in the dark, as in Zostera marina and Phyllospadix scouleri (Harlin 1973). Selective redistribution of photosynthesis products has also been reported in $Z$. americana (Harrison 1978) and in Fucales (Schmitz 1982, Diouris \& Floc'h 1984).

This evidence of transport in Posidonia oceanica lends some support to the results of Ott (1980) and Pirc (1985), who showed that significant amounts of starch accumulate in rhizomes at particular seasons during the year, as well as to those of Bedhomme (1981), who postulated that seasonal variations in leaf 'density' (dry weight versus foliar surface unit) might correspond to the ingoing (and outgoing) movements of organic compounds in the leaves. Likewise in Thalassia testudinum, Capone et al. (1979) stated that the differences between primary production estimates (by the ${ }^{14} \mathrm{C}$ method and by leaf growth measurements) was largely due to the use of photosynthesis products for rhizome growth.

Our values of transfer rate (from 2 to $5 \mathrm{~cm} \mathrm{~h}^{-1}$ ) agree with others measured by means of ${ }^{14} \mathrm{C}: 1.5$ to $9 \mathrm{~cm} \mathrm{~h}^{-1}$ (Jupp 1972), 5 to $10 \mathrm{~cm} \mathrm{~h}^{-1}$ in Laminaria hyperborea (Lüning et al. 1972), and 6 to $10 \mathrm{~cm} \mathrm{~h}^{-1}$ in Saccorhiza dermatodea (Emerson et al. 1982). They are also of the same order of magnitude as ionic migration measured 
in Laminariales by means of ${ }^{32} \mathrm{P}: 1.4$ to $1.7 \mathrm{~cm} \mathrm{~h}^{-1}$ (Floc'h \& Penot 1972), and 3 to $4 \mathrm{~cm} \mathrm{~h}^{-1}$ (Penot et al. 1976). However, they are much lower than those usually given for higher plants (up to $100 \mathrm{~cm} \mathrm{~h}^{-1}$ ).

At present, the main problem in studying these translocation processes remains in the explanation of their variability (seasonal and circadian periodicity, photoregimen), and the finding of their regulating factors.

\section{Transfer of products between host plant and epiphytes}

In unincubated shoots, we found the maximum amount of transferred photosynthates to be in leaf tips. Surprisingly, however, productivity in Posidonia oceanica was always maximal in the middle part of epiphyte-free leaves. This unusual location may have to do with the presence of epiphytes acting as a sink (McRoy \& Goering 1974), as well as the fact that newly formed photosynthates, and redistributed products from the rhizomes, do not follow the same vascular path. We found 0.2 to $5.4 \%$ of the total ${ }^{14} \mathrm{C}$ transferred to be in the epiphytes of shoots adjacent to the incubated shoot (Table 2). In Expt 5, these $5.4 \%$ amounted to a fourth of the total transferred carbon (Table 2). Thus per unit of dry matter weight, more ${ }^{14} \mathrm{C}$ was transferred to the epiphytes than to the leaves of the phanerogam. McRoy \& Goering (1974) reported similar findings in Zostera marina. With regard to these results it is important to recall that epiphytes of $P$. oceanica are not parasites in the strict sense of the term since they do not have penetrating rhizoids or other such specialized organs. Three questions thus arise: (1) What chemical form and by what mechanism is the transfer of labelled carbon between the host-plant and its epiphyte achieved? (2) How much of the carbon excreted by the leaves is used by living epiphytic flora, discounting animal epiphytes and inorganic fraction? (3) What is the purpose of these exchanges with epiphytes?

Insofar as Posidonia oceanica is concerned, these questions cannot presently be satisfactorily answered. But, with respect to the third question, McRoy \& Goering (1974) claim that 2-way exchanges of elements like carbon, nitrogen and phosphorus may enhance primary production in algal epiphytes by giving these organisms access to nutrient content of the sediment. These close interactions between the host plant and its epiphytes may have to do with symbiotic relations for carbon and nitrogen (Goering \& Parker 1972, Patriquin \& Knowles 1972, Head \& Carpenter 1975, Capone \& Taylor 1977).

Acknowledgements. We thank Dr M.-R. Plante-Cuny and Dr J.-C. Fardeau for their valuable advice during the writing of this article. Incubation chambers were made and modified according to a smaller version (2.3 l) kindly lent to us by Dr D.
Bay (STARESO; Calvi, Corsica) whom we thank for his help at the beginning of the experiments. Measuring radioactive ${ }^{14} \mathrm{C}$ would not have been possible without the collaboration of the 'Service de Radio-Agronomie' and particularly Dr J.-C. Fardeau (C.E.A. Cadarache, St-Paul-lez-Durance, France). This work was part of a contract between both the GIS Posidonie and the Agence Française pour la Maitrise de l'Energie (AFME) and the French Ministere de l'Environnement (National Park of Port-Cros).

\section{LITERATURE CITED}

Bay, D. (1978). Etude in situ de la production primaire d'un herbier de Posidonies (Posidonia oceanica [L.] Delile) de la baie de Calvi-Corse. Thèse, Fac. Sci. Univ. Liège, Belgium

Bedhomme, A. L. (1981). Phénologie et production primaire des feuilles de Posidonia oceanica (Linnaeus) Delile dans la baie de Port-Cros: problèmes méthologiques. D. E. A., Université Aix-Marseille II, Fac. Sci. Luminy: 1-43

Ben, V. D. (1971). Les épiphytes des feuilles de Posidonia oceanica sur les côtes francaises de la Méditerranée. Mém. Inst. roy. Sci. nat. Belg. 168: 1-101

Brix, H., Lyngby, J. E. (1985). Uptake and translocation of phosphorus in eelgrass (Zostera marina). Mar. Biol. 90: 111-116

Boudouresque, C. F., Giraud, G., Perret-Boudouresque, M. (1980). Bibliography on vegetation and ecosystems of Posidonia oceanica. Parts I and II. Excerpta Botanica (Sectio B) 20: 125-135

Buggeln, R. G. (1976). The rate of translocation in Alaria esculenta (Laminariales, Phaephyceae). J. Phycol. 12: $439-442$

Buggeln, R. G. (1977). Physiological investigations on Alaria esculenta (Laminariales, Phaeophyceae). II. Role of translocation in blade growth. J. Phycol. 13: 212-218

Buggeln, R. G. (1978). Physiological investigations on Alaria esculenta (Laminariales, Phaeophyceae). III. Exudation by the blades. J. Phycol. 14: 54-56

Capone, D., Taylor, B. F. (1977). Nitrogen fixation (acetylene reduction) in the phyllosphere of Thalassia testudinum. Mar. Biol. 40: 19-28

Capone, D., Penhale, P. A., Oremland, R. S., Taylor, B. F. (1979). Relationship between productivity and $\mathrm{N}_{2}\left(\mathrm{C}_{2} \mathrm{H}_{2}\right)$ fixation in a Thalassia testudinum community. Limnol. Oceanogr. 24: 117-125

Caye, G., Rossignol, M. (1983). Etude des variations saisonnières de la croissance des feuilles et des racines de Posidonia oceanica (L.) Delile. Mar. Biol. 75: 79-88

Diouris, M., Floc'h., J. Y. (1984). Long distance transport of ${ }^{14} \mathrm{C}$-labelled assimilates in the Fucales: directionality, pathway and velocity. Mar. Biol. 78: 199-204

Drew, E. A. (1978). Factors affecting photosynthesis and its seasonal variation in the seagrasses Cymodocea nodosa (Ucria) Aschers., and Posidonia oceanica (L.) Delile in the Mediterranean. J. exp. mar. Biol. Ecol. 31: 173-194

Drew, E. A., Jupp, B. P. (1976). Some aspect of the growth of Posidonia oceanica in Malta. In: Drew, E., Lythgoe, L. Woods, K. (ed.) Underwater research. Academic Press, London, p. 357-367

Emerson, C. J., Buggeln, R. G., Bal, A. K. (1982). Translocation in Saccorhiza dermatodea (Laminariales, Phaeophyceae) anatomy and physiology. Can. J. Bot. 60: 2164-2184

Floc'h, J. Y., Penot, M. (1972). Transport du ${ }^{32} \mathrm{P}$ et du ${ }^{86} \mathrm{Rb}$ chez quelques algues brunes: orientations des migrations et voies de conduction. Physiol. Veg. 10 (4): 677-686

Fresi, E., Saggiomo, V. (1981). Phosphorus uptake and transfer 
in Posidonia oceanica (L.) Delile. Rapp. P.-v. Réun. Commn int. Explor. scient. Mer Méditerr. 27 (2): 136-137

Giraud, G. (1979). Sur une méthode de mesure et de comptage des structures foliaires de Posidonia oceanica (Linnaeus) Delile. Bull. Mus. Hist. nat. Marseille 39: 33-39

Goering, J. $j_{\text {. }}$ Parker, P. L. (1972). Nitrogen fixation by epiphytes on seagrasses. Limnol. Oceanogr. 17: 320-323

Harlin, M. M. (1973). Transfer of products between epiphytic algae and host plants. J. Phycol. 9: 243-248

Harlin, M. M. (1975). Epiphyte-host relations in seagrasses communities. Aquat. Bot. 1: 125-131

Harrison, P. G. (1978). Patterns of uptake and translocation of ${ }^{14} \mathrm{C}$ by Zostera americana Den Hartog in the Laboratory. Aquat. Bot. 5 (1): $87-93$

Hatcher, B. G. (1977). An apparatus for measuring photosynthesis and respiration of intact large marine algae and comparisons of results with those from experiments with tissues segments. Mar. Biol. 43: 381-395

Head, W. D. Carpenter, E. J. (1975). Nitrogen fixation associated with the macroalgae Codium fragile. Limnol Oceanogr. 20: 815-823

Jones, R. C. (1968). Primary productivity of the tropical turtle grass Thalassia testudinum. Bull. mar. Sci. Gulf Caribb. 14 306-341

Jupp, E. A. (1972). Studies on the growth and physiology of attached marine algae. Ph. D. thesis, St. Andrews Univ., Scotland

Libes, M. (1984a). Production primaire d'un herbier à Posidonia oceanica mesurée in situ par la méthode du carbone 14. Thèse de doctorat de spécialité en Ecologie. Université Aix-Marseille II, Fac. Sci. Luminy: 1-199

Libes, M. (1984b). Teneur en pigments chlorophylliens chez Posidonia oceanica et ses épiphytes. In: Boudouresque, C. F., Jeudy de Grissac, A., Olivier, J., (ed.) First Int. Workshop on Posidonia oceanica beds. GIS Posidonie, Marseille, p. 261-269

Lüning, K., Schmitz, K., Willenbrink, S. (1972). Translocation of ${ }^{14} \mathrm{C}$ labelled assimilates in two Laminaria species. Proc. VII Int. Seaw. Symp., Sapporo 7: 420-425

Manley, S. L. (1984). Micronutrient uptake and translocation by Macrocystis pyrifera (Phaeophyta). J. Phycol. 20: 192-201

McRoy, C. P., Barsdate, R. J. (1970). Phosphate absorption in eelgrass. Limnol. Oceanogr. 15: 6-13

McRoy, C. P., Goering, J. J. (1974). Nutrient transfer between the seagrass Zostera marina and its epiphytes. Nature, Lond. 248: 173-174

Molinier, R., Picard, J. (1952). Recherches sur les herbiers de phanérogames marines du littoral méditerranéen français. Annls Inst. Océanogr., Paris 27: 157-234

Nowak, R. (1984). Ultra-ecology: microorganisms on the seagrass Posidonia oceanica (L.) Delile. P.S.Z.N. Mar Ecol. 5 (2): $143-190$

Ott, J. A. (1980). Growth and production in Posidonia oceanica (L.) Delile. P.S.Z.N. Mar. Ecol. 1: 47-64
Patriquin, D., Knowles, R. (1972). Nitrogen fixation in the rhizosphere of marine anigosperms. Mar. B1ol. 16: 49-58

Penhale, P. A. (1977). Macrophyte-epiphyte biomass and productivity in an eelgrass (Zostera marina) community. J. exp. mar. Biol. Ecol. 26: 211-224

Penhale, P. A., Thayer, G. W. (1980). Uptake and transfer of carbon and phosphorus by eelgrass (Zostera marina L.) and its epiphytes. J. exp. mar. Biol. Ecol. 42: 113-125

Penot, M., Floc'h, J. Y., Penot, M. (1976). Physiologie comparée des transports à longue distance chez les végétaux supérieurs et chez les algues marines. Phycologia 15 (3/4): 299-308

Penot, M., Dumay, J., Pellegrini, M. (1985). Contribution à l'étude de la fixation et du transport du ${ }^{14} \mathrm{C}$ chez Cystoseira nodicaulis (Fucales, Cystoseiracea). Phycologia 24 (1): 93-102

Pirc, H. (1985). Growth dynamics in Posidonia oceanica (L.) Delile. I. Seasonal changes of solubles carbohydrates, starch, free amino acids, nitrogen and organic anions in differents parts of the plant. P. S.Z.N. Mar. Ecol.: 141-165

Pottier, J. (1934). Contribution à l'étude du développement de la racine, de la tige et de la feuille des phanérogames Angiospermes. Les monocotylédones marines Françaises: Ruppia maritima L., Cymodocea nodosa Ucria Ascherson, et Posidonia oceanica (L.) Delile. Jacques et Demontrand, Besançon

Schmitz, K. (1982). Translocation of organic compounds in Laminariales. In: Srivastava, L. M. (ed.) Synthetic and degradative processes in marine macrophytes. De Gruyter, Berlin, p. 140-166

Siegel, S. (1956). Non-parametric statistics for the behaviour sciences. McGraw-Hill, New York

Strickland, J. D. H., Parsons, T. R. (1972). A practical handbook of seawater analysis, 2nd edn. Bull. Fish. Res. Bd Can. 167: 1-130

Thelin, I., Giorgi, J. (1984). Production des feuilles dans un herbier superficiel à Posidonia oceanica évaluée par une méthode dérivée de la méthode de Zieman. In: Boudouresque, C. F., Jeudy de Grissac, A., Olivier, J. (ed.) Workshop on Posidonia oceanica beds. GIS Posidonie, Marseille, p. 271-276

Thursby, G. B., Harlin, M. M. (1982). Leaf-root interaction in the uptake of ammonia by Zostera marina. Mar. Biol. 72: 109-112

Vollenweider, R. A. (1974). A manual on methods for measuring primary production in aquatic environments. I.B.P. Handbook 12. Blackwell, Oxford

Wetzel, R. G. (1974). The enclosure of macrophyte communities. In: Vollenweider, R. A. (ed.) A manual on methods for measuring primary production in aquatic environments. I.B.P. Handbook 12. Blackwell, Oxford, p. 101-107

Wetzel, R. G., Penhale, P. (1979). Transport of carbon and excretion of DOC by leaves and roots in seagrasses and their epiphytes. Aquat. Bot. 6: 149-158 